\title{
The effects of rhEPO intervention for perinatal intrauterine herpes virus infection on preventing brain injury in preterm infants
}

\author{
PING TANG ${ }^{1}$, HUIJUAN GUANG ${ }^{2}$ and LING HUANG ${ }^{3}$ \\ ${ }^{1}$ Department of Obstetrics, The Second People's Hospital of Liaocheng, Linqing, Shangdong 252601; \\ ${ }^{2}$ Department of Obstetrics and Gynecology, Hanzhong Municipal People's Hospital, Hanzhong, Shaanxi 723000; \\ ${ }^{3}$ Department VI of Obstetrics, The Central Hospital of Tai'an, Tai'an, Shandong 271000, P.R. China
}

Received June 1, 2017; Accepted September 25, 2017

DOI: 10.3892/etm.2017.5412

\begin{abstract}
The ability of recombinant human erythropoietin (rhEPO) to protect preterm infants against perinatal intrauterine herpes virus infection-induced brain injury was studied. In total, 120 women infected with perinatal intrauterine herpes virus were randomized into four groups: $\mathrm{A}$, $\mathrm{B}, \mathrm{C}$ and $\mathrm{D}$, and were given 1,500 IU (mother, pre-partum), 3,000 IU (mother, pre-partum), $250 \mathrm{IU} / \mathrm{kg}$ (infant, post-natal), and no rhEPO, respectively. Hemoglobin ( $\mathrm{Hb})$, reticulocyte (Ret), hematocrit (Hct), neuron specific enolase (NSE), myelin basic protein (MBP), and S100 protein B (S100B) levels were measured immediately $\left(\mathrm{T}_{0}\right)$ and at 1 week $\left(\mathrm{T}_{1}\right), 2$ weeks $\left(\mathrm{T}_{2}\right)$, and 4 weeks $\left(\mathrm{T}_{3}\right)$ post-delivery. Linear regression analysis was performed to analyze inter-indicator correlation, and ROC risk models were established to determine the predictive value of $\mathrm{Hb}$, Ret and Hct for brain injury immediately after delivery. The brain injury incidence rate of group A (10\%) was significantly lower than group D (33.3\%) and group B $(6.7 \%)$ significantly lower than groups $\mathrm{C}(26.7 \%)$ and $\mathrm{D}$. At $\mathrm{T}_{0}, \mathrm{Hb}$, Ret and Hct in groups $\mathrm{A}$ and $\mathrm{B}$ were significantly higher than in group $\mathrm{C}$ and $\mathrm{D}$, while from $\mathrm{T}_{1}$ to $\mathrm{T}_{3}$, groups $\mathrm{A}, \mathrm{B}$ and $\mathrm{C}$ showed significantly higher values than group D. NSE, MBP and S100B showed an inverse trend, with groups A and B lower at $\mathrm{T}_{0}$ and groups $\mathrm{A}, \mathrm{B}$ and $\mathrm{C}$ lower from $\mathrm{T}_{1}-\mathrm{T}_{3}$. Hb and NSE, MBP and S100B were negatively correlated, while no correlation was found between Ret and NSE, MBP and S100B. Finally, Hct and NSE, MBP and S100B were negatively correlated. The optimal cut-off values for $\mathrm{Hb}$ and $\mathrm{Hct}$ for brain injury diagnosis immediately post-partum were $170 \mathrm{~g} / 1$ (sensitivity 99\%, specificity $95.7 \%$ ) and $28.5 \%$ (sensitivity $79.4 \%$, specificity $100 \%$ ), respectively. Ret did not show predictive value. In conclusion,
\end{abstract}

Correspondence to: Dr Ling Huang, Department VI of Obstetrics, The Central Hospital of Tai'an, 29 Longtan Road, Taishan, Tai'an, Shandong 271000, P.R. China

E-mail: hhrcpb@163.com

Key words: perinatal period, intrauterine herpes, recombinant human erythropoietin, brain injury in preterm infants pre-partum rhEPO treatment showed greater protective effects than post-natal administration, and this may be the regulation of $\mathrm{Hb}$ and Hct levels in post-natal preterm infants. In addition, a dose-dependent effect was displayed.

\section{Introduction}

Brain injury in preterm infants is related to inflammatory responses and viral infections (1). Herpes simplex virus (HSV) infection is one of the common types of intrauterine viral infection, with $\sim 2.5 \%$ incidence in pregnant women and $0.04 \%$ incidence in neonates (2). Many studies have shown that the cytokine-induced inflammatory response is the main mechanism of perinatal infection-induced brain injury. Pathogens are able to enter the fetus via maternal systems, thus increasing the risk of fetal inflammation syndrome, and inflammatory cytokines can enter the fetal brain via the circulation, contributing to adverse neurodevelopmental outcomes. Accordingly, effective and prophylactic intervention in pregnant women with perinatal intrauterine viral infections is critical for protecting the cerebral neurofunction of preterm neonates (3). In the past, recombinant human erythropoietin (rhEPO) was generally used for treating anemia, including gestational anemia, with a high degree of safety (4). However, the non-hematopoietic functions of rhEPO have recently attracted clinical attention, focusing especially on its neuroprotective capabilities. Indeed, the ability of rhEPO to protect against brain injuries has been investigated in neonatal rats (5). At this stage though, the majority of studies have focused on neonates and animal models, with no clinical investigation of prophylactic rhEPO intervention. The present study, having understood the reported safety of rhEPO intervention in pregnant women, investigated the neuroprotective capabilities of rhEPO intervention as an adjuvant therapy in pregnant women infected with intrauterine herpes virus.

\section{Patients and methods}

Patient information. One hundred and twenty women infected with perinatal intrauterine herpes virus treated at the Second People's Hospital of Liaocheng between July, 2012 and 
Table I. Maternal participant baseline data.

\begin{tabular}{|c|c|c|c|c|c|}
\hline Variable & Group A & Group B & Group C & Group D & P-value \\
\hline Age (years) & $26.3 \pm 4.2$ & $26.7 \pm 3.9$ & $27.1 \pm 4.8$ & $26.9 \pm 5.2$ & $>0.05$ \\
\hline Gestational age (weeks) & $32.4 \pm 2.2$ & $31.5 \pm 3.5$ & $31.8 \pm 1.8$ & $32.6 \pm 2.8$ & $>0.05$ \\
\hline Body weight (kg) & $72.6 \pm 10.5$ & $75.6 \pm 11.4$ & $73.2 \pm 12.6$ & $73.7 \pm 13.0$ & $>0.05$ \\
\hline
\end{tabular}

Table II. Fetal baseline data.

\begin{tabular}{|c|c|c|c|c|c|}
\hline Variable & Group A & Group B & Group C & Group D & P-value \\
\hline Gender (male/female) & $16 / 14$ & $18 / 12$ & $15 / 15$ & $14 / 16$ & $>0.05$ \\
\hline Gestational age (weeks) & $31.2 \pm 1.8$ & $31.4 \pm 2.2$ & $30.1 \pm 2.1$ & $31.7 \pm 1.9$ & $>0.05$ \\
\hline Weight $(\mathrm{g})$ & $1725.2 \pm 159.4$ & $1746.5 \pm 161.7$ & $1722.5 \pm 154.9$ & $1736.5 \pm 171.5$ & $>0.05$ \\
\hline 1-min Apgar score & $9.5 \pm 1.4$ & $9.7 \pm 1.6$ & $9.7 \pm 1.8$ & $9.4 \pm 1.6$ & $>0.05$ \\
\hline
\end{tabular}

August, 2014 were selected. The inclusion criteria were defined in accordance with 'Chinese Obstetrics and Gynecology' (6). Selected patients presented fever $\left(>37.5^{\circ} \mathrm{C}\right)$, heart rate $>100$ bpm, fetal heart rate $>160 \mathrm{bpm}$, abnormal amniotic fluid smell, uterine tenderness, $\mathrm{CRP}>8 \mathrm{mg} / \mathrm{l}, \mathrm{WBC}>15 \times 10^{9} / 1$. All selected patients were required to provide voluntary informed written consent prior to enrollment in the study. Participant exclusion criteria were as follows: i) allergy to the selected medicine; ii) having pregnancy-induced hypertension, diabetes, or preeclampsia, other pregnancy-related complications, or serious internal diseases; iii) refusal to provide consent.

Fetus inclusion criteria were as follows: i) gestational age $<37$ weeks, in line with diagnostic criteria for preterm children; ii) presence of maternal pathogens in fetal pharyngeal secretions, urine, or blood. Fetus exclusion criteria were as follows: i) allergy to the selected medicine; ii) presence of any other congenital diseases. Participants were randomly assigned into four groups of 30 each: A, B, C and D. Maternal and fetal baseline data for all four groups are shown in Tables I and II. No significant differences in any parameter were found between any of the groups $(\mathrm{P}>0.05)$. The study was approved by the Ethics Committee of the Second People's Hospital of Liaocheng.

Intervention methodology. Participants in all four groups were given the same baseline intrauterine infection treatment, with rhEPO administration only after their infections were under control. Participants in group A were treated with 1,500 IU rhEPO doses (S20030068; Shanghai HKB Co., Ltd., Shanghai, China) via slow intravenous injection every 3 days until delivery. Participants in group B underwent the same procedure except the dosage was 3,000 IU rhEPO. In group $\mathrm{C}$, neonates were intravenously administered $250 \mathrm{IU} / \mathrm{kg}$ rhEPO 3 times/week from 2-3 days post-natal until 1 month. Participants in group D were not given rhEPO at any time. $\mathrm{Hb}$ levels were closely monitored throughout the study period, with $\mathrm{Hb}$ levels $>220 \mathrm{~g} / \mathrm{l}$ resulting in termination of rhEPO administration to prevent hyper-erythropoiesis.

Measured parameters. The following parameters were measured immediately after delivery $\left(\mathrm{T}_{0}\right)$ and $1\left(\mathrm{~T}_{1}\right), 2\left(\mathrm{~T}_{2}\right)$, and 4 weeks after delivery $\left(\mathrm{T}_{3}\right)$ : hemoglobin $(\mathrm{Hb})$, reticulocyte (Ret), hematocrit (Hct), neuronspecific enolase (NSE), myelin basic protein (MBP), and S100 calcium-binding protein B (S100B). The linear relationships and the correlation coefficient $r$ between $\mathrm{Hb}$, Ret and Hct with NSE, MBP and S100B were analyzed. Receiver operating characteristic (ROC) curve models were established to determine the evaluation values of $\mathrm{Hb}$, Ret and Hct for brain injury in preterm infants and their optimal cut-off values.

Statistical analysis. SPSS 19.0 (IBM, Armonk, NY, USA) was used in data analysis. Measurement data were recorded as (mean $\pm \mathrm{SD}$ ), and the comparison of multiple time-points between the four groups was calculated via repeated measures analysis of variance (rANOVA). Multivariate analysis of variance (MANOVA) was used for single time-point comparisons while least significant difference (LSD) was used for pair-comparisons. Odds ratio (\%) was calculated and Mann-Whitney U test was used to compare pair-data. Chi-square test was applied in mortality and bacterial eradication calculations, data were analyzed via linear correlation and $\mathrm{P}<0.05$ indicated statistical significance.

\section{Results}

Incidence of brain injury. The incidence of brain injury in groups A, B, C and D were 10\% (3/30), 6.7\% (2/30), $26.7 \%(8 / 30)$, and $33.3 \%$ (10/30), respectively. The difference between group $\mathrm{A}$ and groups $\mathrm{B}$ and $\mathrm{C}$ were not statistically significant $\left(\chi^{2}=0.218, \mathrm{P}=0.640 ; \chi^{2}=2.783, \mathrm{P}=0.095\right.$, respectively). However, group A was significantly different than group $\mathrm{D}\left(\chi^{2}=4.812, \mathrm{P}=0.028\right)$. group $\mathrm{B}$ was also significantly different from groups $\mathrm{C}$ and $\mathrm{D}\left(\chi^{2}=4.320, \mathrm{P}=0.038 ; \chi^{2}=6.667\right.$, $\mathrm{P}=0.010$, respectively), while groups $\mathrm{C}$ and $\mathrm{D}$ were not statistically significant $\left(\chi^{2}=0.318, P=0.573\right)$.

Multiple time-point Hb, Ret and Hct level comparisons between groups. Hb levels in all four groups showed a decreasing trend over time (Table III). At $\mathrm{T}_{0}$, Hb levels in groups A and $\mathrm{B}$ were significantly higher than in groups $\mathrm{C}$ and $\mathrm{D}(\mathrm{P}<0.05)$ while no 
Table III. Multiple time-point Hb, Ret and Hct level comparisons.

\begin{tabular}{|c|c|c|c|c|c|}
\hline Variable & Time-point & Group A $(n=30)$ & Group B $(n=30)$ & Group C $(n=30)$ & Group D $(n=30)$ \\
\hline \multirow[t]{4}{*}{$\mathrm{Hb}(\mathrm{g} / \mathrm{l})$} & $\mathrm{T}_{0}$ & $171.6 \pm 14.8$ & $173.8 \pm 15.3$ & $159.9 \pm 17.2^{\mathrm{a}, \mathrm{b}}$ & $165.2 \pm 16.8^{\mathrm{a}, \mathrm{b}}$ \\
\hline & $\mathrm{T}_{1}$ & $156.3 \pm 20.4$ & $158.5 \pm 19.5$ & $161.8 \pm 13.4$ & $142.6 \pm 20.2^{\mathrm{a}-\mathrm{c}}$ \\
\hline & $\mathrm{T}_{2}$ & $135.5 \pm 18.7$ & $137.3 \pm 20.5$ & $141.3 \pm 13.3$ & $112.5 \pm 21.6^{\mathrm{a}-\mathrm{c}}$ \\
\hline & $\mathrm{T}_{3}$ & $109.9 \pm 16.5$ & $112.5 \pm 15.4$ & $115.4 \pm 12.9$ & $90.4 \pm 14.3^{\mathrm{a}-\mathrm{c}}$ \\
\hline F-value & & 6.369 & 5.493 & 5.894 & 7.610 \\
\hline P-value & & 0.024 & 0.049 & 0.039 & 0.014 \\
\hline \multirow[t]{4}{*}{$\operatorname{Ret}\left(\mathrm{x} 10^{9}\right)$} & $\mathrm{T}_{0}$ & $22.4 \pm 9.7$ & $24.1 \pm 12.9$ & $18.4 \pm 10.2^{\mathrm{a}, \mathrm{b}}$ & $18.1 \pm 9.5^{\mathrm{a}, \mathrm{b}}$ \\
\hline & $\mathrm{T}_{1}$ & $24.5 \pm 10.3$ & $24.6 \pm 13.4$ & $27.5 \pm 14.2$ & $17.3 \pm 10.2^{\mathrm{a}-\mathrm{c}}$ \\
\hline & $\mathrm{T}_{2}$ & $22.7 \pm 11.5$ & $21.2 \pm 10.3$ & $26.2 \pm 13.5$ & $17.7 \pm 11.2^{\mathrm{a}-\mathrm{c}}$ \\
\hline & $\mathrm{T}_{3}$ & $24.5 \pm 12.4$ & $20.4 \pm 11.7$ & $24.8 \pm 11.3$ & $18.6 \pm 12.7^{\mathrm{a}-\mathrm{c}}$ \\
\hline F-value & & 3.169 & 2.693 & 4.775 & 3.031 \\
\hline P-value & & 0.136 & 0.271 & 0.069 & 0.142 \\
\hline \multirow[t]{4}{*}{$\operatorname{Hct}(\%)$} & $\mathrm{T}_{0}$ & $31.4 \pm 6.2$ & $32.5 \pm 5.8$ & $27.1 \pm 4.9^{\mathrm{a}, \mathrm{b}}$ & $26.6 \pm 5.3^{\mathrm{a}, \mathrm{b}}$ \\
\hline & $\mathrm{T}_{1}$ & $28.6 \pm 5.4$ & $31.7 \pm 5.6$ & $32.5 \pm 5.5$ & $25.4 \pm 4.3^{\mathrm{a}-\mathrm{c}}$ \\
\hline & $\mathrm{T}_{2}$ & $33.6 \pm 5.8$ & $34.1 \pm 6.5$ & $31.4 \pm 6.3$ & $24.1 \pm 5.9^{\mathrm{a}-\mathrm{c}}$ \\
\hline & $\mathrm{T}_{3}$ & $34.1 \pm 5.6$ & $37.5 \pm 7.5$ & $38.4 \pm 7.4$ & $23.4 \pm 6.3^{\mathrm{a}-\mathrm{c}}$ \\
\hline F-value & & 7.893 & 9.963 & 5.336 & 4.116 \\
\hline P-value & & 0.001 & $<0.01$ & 0.056 & 0.089 \\
\hline
\end{tabular}

$\mathrm{P}<0.05$ vs. groups $\mathrm{A}^{\mathrm{a}}, \mathrm{B}^{\mathrm{b}}$ and $\mathrm{C}^{\mathrm{c}}$. Hb, hemoglobin; Ret, reticulocyte; Hct, hematocrit.

differences were observed between groups $\mathrm{C}$ and $\mathrm{D}(\mathrm{P}>0.05)$. At $\mathrm{T}_{1}, \mathrm{~T}_{2}$ and $\mathrm{T}_{3}, \mathrm{Hb}$ levels were not significantly different between the four groups ( $\mathrm{P}>0.05)$, although groups $\mathrm{A}, \mathrm{B}$ and $\mathrm{C}$ all showed higher levels than group $\mathrm{D}$. Ret levels were not different between groups $\mathrm{A}$ and $\mathrm{B}$ at any time-point $(\mathrm{P}>0.05)$, but Ret levels in groups $\mathrm{A}$ and $\mathrm{B}$ were higher than those in groups $\mathrm{C}$ and $\mathrm{D}$ at $\mathrm{T}_{0}(\mathrm{P}<0.05)$. In addition, Ret levels in groups $\mathrm{A}, \mathrm{B}$ and $\mathrm{C}$ were higher than in group $\mathrm{D}$ at $\mathrm{T}_{1}-\mathrm{T} 3$ $(\mathrm{P}<0.05)$. Finally, Hct levels were higher in group $\mathrm{B}$ than group $\mathrm{A}$ at $\mathrm{T}_{0}$, but the difference was not statistically significant $(\mathrm{P}>0.05)$. However, Hct levels in groups $\mathrm{A}$ and $\mathrm{B}$ were significantly higher than in groups $\mathrm{C}$ and $\mathrm{D}(\mathrm{P}<0.05)$. At $\mathrm{T}_{1}$, $\mathrm{T}_{2}$ and $\mathrm{T}_{3}$, Hct levels in groups $\mathrm{A}, \mathrm{B}$ and $\mathrm{C}$ were significantly higher than in group $\mathrm{D}(\mathrm{P}<0.05)$.

Differences in specific brain injury indicators in preterm infants. As shown in Table IV, NSE, MBP and S100B levels were significantly lower in groups $\mathrm{A}$ and $\mathrm{B}$ vs. groups $\mathrm{C}$ and $\mathrm{D}$ at $\mathrm{T}_{0}(\mathrm{P}<0.05)$, while at $\mathrm{T}_{1}, \mathrm{~T}_{2}$ and $\mathrm{T}_{3}$, there was no significant difference among groups $\mathrm{A}, \mathrm{B}$ and $\mathrm{C}(\mathrm{P}>0.05)$, but all three showed significantly lower NSE, MBP and S100B levels than group D $(\mathrm{P}<0.05)$.

Correlation between blood indicators and specific brain injury indicators. As shown in Table V, there was a negative correlation between $\mathrm{Hb}$ and NSE, MBP and S100B $(\mathrm{P}<0.05)$, while Ret was not significantly correlated with NSE, MBP or S100B ( $>>0.05)$. Hct was negatively correlated with NSE, $\mathrm{MBP}$ and $\mathrm{S} 100 \mathrm{~B}(\mathrm{P}<0.05)$.

ROC brain injury prediction model using umbilical vein blood immediately after delivery. ROC model results presented an area under the curve (AUC) of 0.992 for $\mathrm{Hb}$, with standard error 0.006, asymptotic significance $\mathrm{P}<0.01,95 \%$ CI, 0.980-1.000, optimal cut-off value 170, and sensitivity $99 \% /$ specificity $95.7 \%$. The Ret ROC model presented an AUC of 0.465, with standard error 0.062 , asymptotic significance $\mathrm{P}=0.608$, and $95 \% \mathrm{CI}$, $0.344-0.587$; this indicated that Ret had no predictive value for brain injury. Finally, Hct presented an AUC of 0.934, with standard deviation 0.023 , asymptotic significance $\mathrm{P}<0.01$, 95\% CI, 0.889-0.980, optimal cut-off value 28.5, and sensitivity $79.4 \%$ /specificity $100 \%$ (Fig. 1).

\section{Discussion}

It is clinically recognized today that preterm infant brain injury is mainly related to hypoxia/ischemia and intrauterine infections, with the most common type of brain injury being white matter lesions (7). HSV is one of the common types of intrauterine infection, and studies have confirmed that infants can be infected with HSV at birth, manifesting as lesions of the central nervous system and skin (8). Different viral infections have affinity for different organs, thus leading to significant individual differences in lesion profile. Recent research indicates that HSV-infected infants present microcephaly, heart abnormalities and neuropsychiatric disorders (9). Indeed, research has indicated that $\sim 30 \%$ of preterm deliveries are intrauterine infection-related (10). The main mechanism of intrauterine infection-induced brain injury is fetal blood-brain barrier permeability induced by circulating microorganismstimulated inflammatory factors. This allows microorganisms to enter the fetal brain, causing injury and fever $(11,12)$. Some researchers believe that fever at delivery could aggravate 
Table IV. Differences in specific brain injury indicators in preterm infants.

\begin{tabular}{|c|c|c|c|c|c|}
\hline Indicator & Time-point & Group A & Group B & Group C & Group D \\
\hline \multirow[t]{4}{*}{ NSE (pg/ml) } & $\mathrm{T}_{0}$ & $1.9 \pm 0.5$ & $1.5 \pm 0.2$ & $2.5 \pm 0.5^{\mathrm{a}, \mathrm{b}}$ & $2.6 \pm 0.6^{\mathrm{a}, \mathrm{b}}$ \\
\hline & $\mathrm{T}_{1}$ & $1.9 \pm 0.3$ & $1.8 \pm 0.5$ & $2.0 \pm 0.4$ & $2.5 \pm 0.4^{\mathrm{a}-\mathrm{c}}$ \\
\hline & $\mathrm{T}_{2}$ & $1.8 \pm 0.2$ & $1.9 \pm 0.2$ & $1.8 \pm 0.3$ & $2.3 \pm 0.4^{\mathrm{a}-\mathrm{c}}$ \\
\hline & $\mathrm{T}_{3}$ & $1.3 \pm 0.1$ & $1.5 \pm 0.1$ & $1.4 \pm 0.2$ & $2.2 \pm 0.4^{\mathrm{a}-\mathrm{c}}$ \\
\hline F-value & & 13.007 & 15.960 & 27.582 & 8.369 \\
\hline P-value & & $<0.01$ & $<0.01$ & $<0.01$ & 0.001 \\
\hline \multirow[t]{4}{*}{$\mathrm{MBP}(\mathrm{pg} / \mathrm{ml})$} & $\mathrm{T}_{0}$ & $0.7 \pm 0.2$ & $0.6 \pm 0.1$ & $0.8 \pm 0.2^{\mathrm{a}, \mathrm{b}}$ & $0.9 \pm 0.2^{\mathrm{a}, \mathrm{b}}$ \\
\hline & $\mathrm{T}_{1}$ & $0.5 \pm 0.3$ & $0.5 \pm 0.3$ & $0.5 \pm 0.2$ & $0.9 \pm 0.2^{\mathrm{a}-\mathrm{c}}$ \\
\hline & $\mathrm{T}_{2}$ & $0.3 \pm 0.4$ & $0.4 \pm 0.2$ & $0.4 \pm 0.1$ & $0.8 \pm 0.1^{\mathrm{a}-\mathrm{c}}$ \\
\hline & $\mathrm{T}_{3}$ & $0.2 \pm 0.09$ & $0.3 \pm 0.1$ & $0.3 \pm 0.1$ & $0.8 \pm 0.2^{\mathrm{a}-\mathrm{c}}$ \\
\hline F-value & & 28.693 & 17.525 & 8.582 & 4.696 \\
\hline P-value & & $<0.01$ & $<0.01$ & 0.041 & 0.121 \\
\hline \multirow[t]{4}{*}{ S100B } & $\mathrm{T}_{0}$ & $4.2 \pm 1.0$ & $4.1 \pm 0.9$ & $5.4 \pm 1.4^{\mathrm{a}, \mathrm{b}}$ & $5.6 \pm 2.3^{\mathrm{a}, \mathrm{b}}$ \\
\hline & $\mathrm{T}_{1}$ & $3.9 \pm 1.6$ & $4.0 \pm 1.5$ & $5.1 \pm 1.3$ & $5.5 \pm 2.4^{\mathrm{a}-\mathrm{c}}$ \\
\hline & $\mathrm{T}_{2}$ & $3.8 \pm 1.9$ & $4.0 \pm 1.8$ & $4.2 \pm 1.2$ & $4.9 \pm 1.9^{\mathrm{a}-\mathrm{c}}$ \\
\hline & $\mathrm{T}_{3}$ & $4.1 \pm 1.2$ & $3.9 \pm 1.3$ & $3.7 \pm 1.1$ & $4.8 \pm 2.0^{\mathrm{a}-\mathrm{c}}$ \\
\hline F-value & & 10.960 & 5.916 & 29.398 & 5.226 \\
\hline P-value & & $<0.01$ & 0.067 & $<0.01$ & 0.089 \\
\hline
\end{tabular}

$\mathrm{P}<0.05$ vs. groups $\mathrm{A}^{\mathrm{a}}, \mathrm{B}^{\mathrm{b}}$ and $\mathrm{C}^{\mathrm{c}}$. NSE, neuron specific enolase; MBP, myelin basic protein; $\mathrm{S} 100 \mathrm{~B}, \mathrm{~S} 100$ protein $\mathrm{B}$.

Table V. Correlation between blood indicators and specific brain injury indicators.

\begin{tabular}{lccr}
\hline Independent variables & NSE (r-, P-value) & MBP (r-, P-value) & S100B (r-, P-value) \\
\hline $\mathrm{Hb}$ & $-0.341,0.009$ & $-0.625,<0.01$ & $-0.442,<0.01$ \\
$\mathrm{Ret}$ & $-0.125,0.576$ & $-0.046,0.889$ & $-0.133,0.421$ \\
$\mathrm{Hct}$ & $-0.844,<0.01$ & $-0.136,0.042$ & $-0.643,<0.01$ \\
\hline
\end{tabular}

NSE, neuron specific enolase; MBP, myelin basic protein; S100B, S100 protein B; Hb, hemoglobin; Ret, reticulocyte; Hct, hematocrit.

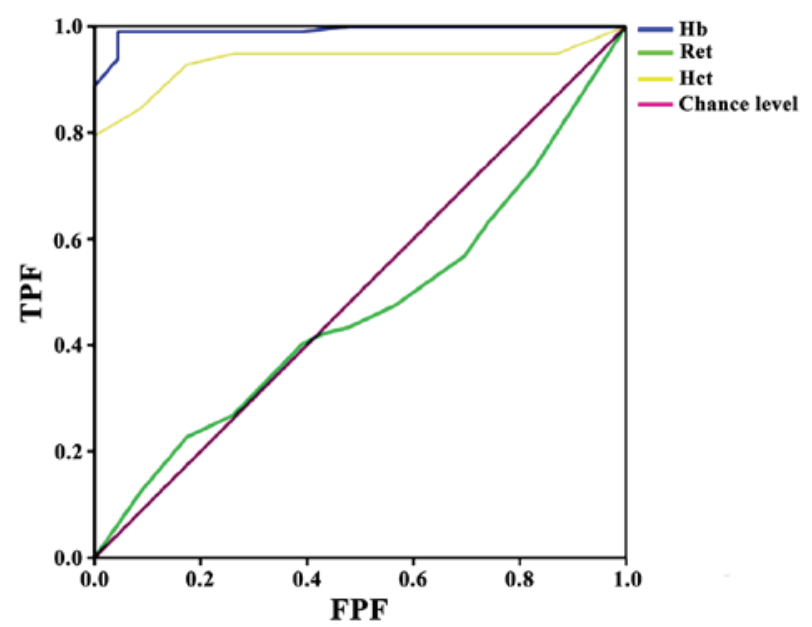

Figure 1. Receiver operating characteristic (ROC) model predictive value for brain injury for hemoglobin $(\mathrm{Hb})$, reticulocyte (Ret) and hematocrit (Hct) values measured immediately after delivery. Hb area under the curve (AUC), 0.992; Ret AUC 0.465; Hct AUC, 0.934. Hb and Hct demonstrated predictive value $(\mathrm{P}<0.05)$ while Ret did not have predictive value $(\mathrm{P}<0.05)$. PS: TPF, sensitivity; FPF, 1-specificity. hypoxia/ischemia in fetal brain, and cerebral palsy incidence has been found to increase 9 -fold (13). In addition, studies have demonstrated that 24-32 weeks of gestational age was the most vulnerable period for fetal white matter. This neurodevelopment stage is roughly equivalent to 2-5 day old neonatal rats, which have been found to be susceptible to infection and hypoxia-induced inflammation $(14,15)$. Therefore, it is entirely possible that the intrauterine infected fetus may have already developed brain injury before delivery.

Apart from its hematopoietic function, EPO also has a neuro-protective role. Preliminary findings have indicated that it may be involved in brain cytokine-manipulated biological regulation, although the mechanism is unclear $(16,17)$. rhEPO administration in an intrauterine fetal hypoxia/ischemia rat model was detected in the pups, indicating that rhEPO breached the blood-brain barrier and protected the fetal brain in the third trimester. However, this particular study investigated uterine hypoxia/ischemia (18) and contradicted earlier studies suggesting that rhEPO could not breach the blood-brain barrier (19). Studies have indicated that brain 
hypoxia/ischemia can be induced by anemia (20), and thus, we investigated blood condition indicators such as $\mathrm{Hb}$, Ret and Hct. Indeed, we found that maternal rhEPO administration resulted in elevated $\mathrm{Hb}$, Ret and Hct levels in infants immediately after delivery. Infants given post-natal rhEPO showed slow decline in $\mathrm{Hb}$, Ret and Hct levels over time. ROC modeling demonstrated that the $\mathrm{Hb}$ and Hct levels measured immediately after delivery could predict brain injury incidence that could not be corrected with post-delivery administration, indicating hysteresis and that infants may have already developed irreversible brain injury by post-delivery administration. In addition, we found that the aforementioned fetus blood indicators were correlated with the specific brain injury indicators NSE, MBP and S100B, suggesting a probable relationship between preterm infant brain injury and anemia (21). Although animal experiments have indicated that low $\mathrm{Hb}$ levels can increase stroke risk (22), no studies regarding the relationship between $\mathrm{Hb}$ and brain injury have been reported until this study. The ROC model established in this study found that the optimal cut-off value for $\mathrm{Hb}$ was 170 and for Hct was 28.5, suggesting an increasing rate of brain injury when $\mathrm{Hb}$ and Hct levels were lower than their cutoff values in preterm infants after delivery. In addition, early administration of rhEPO before delivery may correct low immediately post-delivery $\mathrm{Hb}$ and Hct levels, thereby reducing brain injury risk.

In conclusion, maternal rhEPO intervention in intrauterine HSV-infected women during pregnancy has predictive value on preterm infant brain injury, with a dose-effect relationship. However, to further prove this predictive relationship, animal experiments and studies with a large quantity of sample are still required.

\section{References}

1. Barton SK, Tolcos M, Miller SL, Roehr CC, Schmölzer GM, Davis PG, Moss TJ, LaRosa DA, Hooper SB and Polglase GR: Unraveling the links between the initiation of ventilation and brain injury in preterm infants. Front Pediatr 3: 97, 2015.

2. Pichler M, Staffler A, Bonometti N, Messner H, Deluca J, Thuile T, Kluge R, Schmuth M and Eisendle K: Premature newborns with fatal intrauterine herpes simplex virus-1 infection: First report of twins and review of the literature. J Eur Acad Dermatol Venereol 29: 1216-1220, 2015.

3. Shi J and Mu D: Intrauterine infection and neonate brain injury. J Clin Pediatr 33: 767-770, 2015.

4. Kashiwagi M, Breymann C, Huch R and Huch A: Hypertension in a pregnancy with renal anemia after recombinant human erythropoietin (rhEPO) therapy. Arch Gynecol Obstet 267: 54-56, 2002.

5. Yuan XS, Bian XX, Wei WF, Tang Y and Bao Q: Effect of recombinant human erythropoietin expressions of apoptosis genes in rats following traumatic brain injury. Trop J Pharm Res 15: 695-699, 2016.
6. Cao Z: Chinese Obstetrics and Gynecology. 2nd edition. People's Medical Publishing House Co., Ltd., Beijing, p379, 2004.

7. Kidokoro H, Anderson PJ, Doyle LW, Woodward LJ, Neil JJ and Inder TE: Brain injury and altered brain growth in preterm infants: Predictors and prognosis. Pediatrics 134: e444-e453, 2014.

8. Al-Fadhli M and Saraya M: Herpes Zoster infection in an infant. J Kuwait Med Assoc 46: 256-257, 2014.

9. Fleiss B, Guillot PV, Titomanlio L, Baud O, Hagberg H and Gressens P: Stem cell therapy for neonatal brain injury. Clin Perinatol 41: 133-148, 2014.

10. Chang $\mathrm{L}$ and $\mathrm{Li} \mathrm{W}$ : Intrauterine infection and preterm infant disease. J Appl Clin Pediatr 28: 1041-1043, 2013.

11. Zhang Z, Li A and Xiao X: Risk factors for intrauterine infection with hepatitis B virus. Int J Gynaecol Obstet 125: 158-161, 2014.

12. Kemp MW: Preterm birth, intrauterine infection, and fetal inflammation. Front Immunol 5: 574-574, 2014.

13. Bennet L, Booth L and Gunn AJ: Potential biomarkers for hypoxic-ischemic encephalopathy. Semin Fetal Neonatal Med 15: 253-260, 2010.

14. Northam GB, Liégeois F, Chong WK, Wyatt JS and Baldeweg T: Total brain white matter is a major determinant of IQ in adolescents born preterm. Ann Neurol 69: 702-711, 2011.

15. Thiebaugeorges O, Fresson J, Audibert F, Guihard-Costa AM, Frydman R and Droulle P: Diagnosis of small-for-gestational-age fetuses between 24 and 32 weeks, based on standard sonographic measurements. Ultrasound Obstet Gynecol 16: 49-55, 2000.

16. Uchikura Y, Matsubara K, Matsubara Y, Mori M, Nabeta M, Hashimoto H, Fujioka T, Hamada K and Nawa A: Nucleated red blood cells are involved in endothelial progenitor cell proliferation in umbilical venous blood of preeclamptic patients. Hypertens Res Pregnancy 1: 46-51, 2013.

17. Lund A, Lundby C and Olsen NV: High-dose erythropoietin for tissue protection. Eur J Clin Invest 44: 1230-1238, 2014.

18. Yang W, Cheng Z and Dai H: Calcium concentration response to uterine ischemia: A comparison of uterine fibroid cells and adjacent normal myometrial cells. Eur J Obstet Gynecol Reprod Biol 174: 123-127, 2014

19. Zhiyuan Q, Qingyong L, Shengming H and Hui M: Protective effect of rhEPO on tight junctions of cerebral microvascular endothelial cells early following traumatic brain injury in rats. Brain Inj 30: 462-467, 2016.

20. Osredkar D, Thoresen M, Maes E, Flateb $\varnothing$ T, Elstad M and Sabir H: Hypothermia is not neuroprotective after infection-sensitized neonatal hypoxic-ischemic brain injury. Resuscitation 85: 567-572, 2014.

21. Blackburn S: Brain injury in preterm infants: Pathogenesis and nursing implications. Newborn Infant Nurs Rev 16: 8-12, 2016.

22. Lieber BA, Taylor B, Appelboom G, Prasad K, Bruce S, Yang A, Bruce E, Christophe B and Connolly ES Jr: Meta-analysis of telemonitoring to improve HbA1c levels: Promise for stroke survivors. J Clin Neurosci 22: 807-811, 2015.

(i) $(9)$ This work is licensed under a Creative Commons Attribution-NonCommercial-NoDerivatives 4.0 International (CC BY-NC-ND 4.0) License. 